\title{
The Discourse of Common People Represented in Javanese Version of Abu Nawas Stories
}

\author{
Mundi Rahayu ${ }^{1, *}$ \\ ${ }^{1}$ Universitas Islam Negeri Maulana Malik Ibrahim Malang, Indonesia \\ *Corresponding author. Email: mundi@bsi.uin-malang.ac.id
}

\begin{abstract}
This paper explores the position of the ordinary people represented in the Javanese version of Abu Nawas stories. The Javanese version of Abu Nawas is interesting because of its position as a translation from Arabic to be presented to the Javanese audience in 1933. The main characters of the stories are Abu Nawas and Sultan Harun Ar-Rasyid. Abu Nawas was a low-class person with a close relationship with the King, Sultan Harun Al Rasyid. The stories have been part of the golden age of Arabic literature, and their popularity makes them translated and adapted into many other languages and other forms. This paper explores how the low-class people or common people are represented in the Javanese version of Abu Nawas. To answer this question, the article applies Critical Discourse Analysis to figure out how the low-class people or common people are represented. The result shows that the Javanese version of Abunawas goes through some changes in words and meaning. The common people represented in the stories are Abu Nawas himself and other minor characters. Most of the common people are represented as poor and have to negotiate with the socially high-rank people, like the merchant, the judge, and the Sultan. The poor people's position is less powerful in negotiating with high-ranking people. In the negotiation process, Abu Nawas takes the role of advocate for the poor. This research covers one aspect of the stories, and many other aspects can be analyzed from the stories for the other researchers interested in this topic.
\end{abstract}

Keywords: Abu Nawas, common people, Javanese, CDA, low-class people

\section{INTRODUCTION}

Abu Nuwas (ca. 756-813) was the most famous Arab poet of the Abbasid era. His style was extravagant, and his compositions reflected well the licentious manners of the upper classes of his day [1]. Abu Nuwas had been a prolific poet in the Arabic language as a poet. He is well known around the world. In his book "Abu Nuwas: A Genius of Poetry," Phillip Kennedy described that Medieval Arab society produced a fabulously, perhaps uniquely rich tradition of poetry that had an essential role in defining cultural identity in pre-Islamic Arabia and the Muslim world alike [2]. The popularity of Abu Nuwas goes along with the spread of the Muslim world. In Indonesia, Abu Nuwas is more popularly known for his tales. Not only in the Indonesian language but the tales of Abu Nuwas were also translated into the Javanese language, into Abu Nawas, which was published in 1930 [3]. This current paper explores the Javanese version of
Abu Nawas tales, notably, by focusing on the analysis of how the common people are represented in the stories.

Some researchers have done many studies on Abu Nawas in Western and Eastern scholars. Phillip Kennedy is one of the scholars who studied Abu Nuwas in more detail, especially his poetic style and analysis of his poems. According to Kennedy, the most prominent works of Abu Nawas gave the marker of poetic style in his era. In this study, Abu Nuwas was prominent in two Arabic genres: the wine poem and the hunting poem [2][4]. The other scholar who studied Abu Nuwas was W.H. Ingrams, who wrote Abu Nuwas in Life and in Legend [5]. In the book, Ingrams divided the discussion of Abu Nuwas into three categories, Abu Nuwas in actual, in apocryphal, and in mythical.

The first part of Ingram's book, entitled Actual, says in detail about Abu Nuwas's personal data, whose personal name was Hal Asan, and he was born about the 
year 756 at al-Ahwaz not far from the frontiers of modern Iraq. His father was a native of Damascus, and he was a soldier, belonged to the Hakami tribe, and his mother was a Persian. In this part, Ingrams interwove the life journey of young Abu Nuwas from childhood and his prominent poetic talent that attracted the Caliph, so that The Caliph summoned Abu Nuwas to become one of his court poets. In this part, Abu Nuwas expressed his life experiences into poems so that people get pictures of the life of the poet and the court in that era. In the second part, the apocryphal, Ingrams told us many tales and stories of Abu Nawas that were not a fact or a true story. The tales of Abu Nuwas included in the tales One Thousand and One Night (Arabian Nights) belonged to the apocryphal stories. People made the stories by using the character of Abu Nuwas and the Harun Ar Rasyid. Many of the Arabian Nights' stories were then translated into many languages. The third part is Abu Nuwas as a mythical figure, with the case in the Swahili of Zanzibar. Abu Nuwas was known as Kibunwasi, Bunwasi, Banawasi or Abunwasi or Abunawasi. Swahili's conception of him is as small and cunning, and Banawasi has become a proper name meaning "a man who always has an answer ready, who excels in repartee, a man in fact who laughs best because he always laughs last." So, the personality of the actual Abu Nuwas was disappeared in Swahili [6].

The stories of Abu Nawas are also popularly known in the classical Malay literature as written by Liaw Yock Fang that classified the story of Abu Nawas into the Islam period of Malay literature [7]. Although it belongs to classical literature, Abu Nawas has been alive among people up to now due to the witty and clever personality of Abu Nawas' character. Nowadays, we can find out the story of Abu Nawas in many contemporary writings in popular Indonesian newspapers such as Republika, Kumparan, CNN, and others [8]. In the contemporary writings of Abu Nawas in Indonesia, he is well known as a clever and witty common person. He met the challenges of the Caliph, Harun Ar Rasyid, and solved the problems he encountered [9]. His ideas and logic have inspired other stories, from the anecdote and funny stories in the online portal to the stories delivered through animated movies [10]. In those new stories, some did not refer to or mention the Abu Nawas stories as the reference, but from the reading of Abu Nawas stories, we can find out the similarities in the plot or the stories.

The tales of Abu Nawas were translated into the Javanese language in 1933. The manuscript was entitled "Abu Nawas: Petikan saking carios carios kino" [11]. The Javanese version of Abu Nawas was anonymously translated (using a pseudo name, Petruk), and it came to the Javanese audience before the Indonesian independence. It is interesting then to find out how is the Javanese version of Abu Nawas presents the ordinary people or, in popular Javanese term, "wong cilik". Unfortunately, there is a lack of study on the Javanese version of Abu Nawas, although there are some on the
Indonesian version. Finding this gap, the present research is aimed to fill in the gap by focusing on the representation of common people in the stories of $\mathrm{Abu}$ Nawas.

The name Abu Nawas refers to a poet popularly in the Abbasid era. In addition, he is also known as the main character in the stories. As the stories tell us, Abunawas is commonly perceived as witty, funny and smart, characteristics. The stories were written in Malay and adapted into Javanese literature. The Javanese version of Abunawas was rarely discussed. Therefore, this paper is intended to find out how the Javanese version adapted the stories of Abu Nawas. This study explores the discourse of common people represented in the Javanese version of Abu Nawas, which was written by Petruk (pseudo name) and published by Balai Pustaka in 1930.

The Javanese version of Abu Nawas uses the Javanese language with the translator using pen-name Petruk. Petruk is the character's name in traditional Javanese puppet or wayang, representing ordinary people. He is one of the Punokawan, four comedic figures common in the medium [12]. Punokawan is a group of characters as one harmonious family that provide comic relief in the stories. The punokawan did not only take the role of the clown; instead, they also served to speak to the audience and convey ideas of the dhalang (puppeteer). Petruk is represented as the middle son; he is depicted as having long limbs and a long nose, which is generally considered his most distinctive feature. The use of the pen-name Petruk as the translator implies that the translator represented himself like the character of Petruk in puppetry, a common person having not very serious main roles, but it is needed in the wayang performance.

\section{METHOD}

The current study takes a Javanese version of Abu Nawas as the object of study. In Indonesian literature, the stories of $\mathrm{Abu}$ Nawas were first translated into the Indonesian language by Nur Sultan Iskandar. In Iskandar's book of Abu Nawas, the figure is popular among Indonesian as an ordinary person who is witty and clever. However, he is closed to the King of Baghdad, Sultan Harun Al Rasyid, and takes many challenges. In the Javanese version, the tales of Abu Nawas are almost the same as the Indonesian version, but some words are localized with the Javanese language.

The object of the current study is Abunawas in Javanese version, Abunawas (Book 1 and 2) told by Petruk (pseudo name), published by Wèltêprèdhên: Bale Pustaka in 1930. This version is digitized and uploaded to www.sastra.org. The Javanese title is "Abu Nawas; Pêthikan saking cariyos-cariyos kina. Jilid 1 dan Jilid 2." [Abu Nawas; adapted from old stories. Book 1 and 2]. The first book of Abu Nawas consists of ten stories, and 
the second serial consists of seven stories. All of the stories focus on the main characters, Abu Nawas and the Sultan Harun Al Rasyid (the king of Baghdad) called Prabu Harun Al Rasid in the Javanese version.

The analysis of the story employs Critical Discourse Analysis by Fairclough, which provides three levels of analysis. The first level, micro-level analysis, discusses language use: words, metaphor, and syntax. Second, meso-level analysis deals with the production and consumption of the text, considering that the text and people are mediated through the discourse practice, in which a text is produced and consumed. Finally, the macro-level analysis is the socio-political context of the issue [13].

\section{RESULT}

The Abu Nawas stories in the Javanese version can be seen from the following list. There are ten titles in the first book and seven titles in the second book. Bale Pustaka published the manuscripts in 1933, and nowadays, this manuscript has been digitalized so that we can access the material online.
The lists of the titles above demonstrate that all of the stories take Abunawas as the main character. And the other main character is Sultan Harun Ar Rasyid. Those 27 titles show how Abunawas did some tricks to win the negotiation. The themes of the story represent Abunawas as the winner or the hero.

\section{DISCUSSION}

In the Javanese version of Abu Nawas stories, there are some changes since translation needs to pay attention to the cultural context of the L2. The changes can be seen, first from the writing of the name Abu Nawas. In Arabic, it is commonly written Abu Nuwas or Abu Nawas. Abu is a salutation word, meaning $\mathrm{Mr}$ or Father. It is said that Abu Nuwas got his name because of his long hair; he acquired the name Abu Nuwas (Father of Ringlets) [14]. In the Javanese language, "Abu" is considered the name so that the name is written in one word, as "Abunawas." This way of writing the name shows the localization of the naming and becomes familiar for Javanese speakers. As the stories were translated into the Javanese language, it is intended to be acceptable and closed to Javanese people.

Table 1. The list of Stories in Book 1

\begin{tabular}{|c|c|c|}
\hline No & Stories & Theme \\
\hline 1.1 & $\begin{array}{l}\text { Abunawas api-api edan [Abunawas pretends to be } \\
\text { crazy]. }\end{array}$ & Abunawas avoid the appointment as a judge \\
\hline 1.2 & $\begin{array}{l}\text { Abunawas kalihan sudagar Mêsir [Abunawas and the } \\
\text { Egyptian Merchant] }\end{array}$ & $\begin{array}{l}\text { The merchant was defeated by penghulu, but } \\
\text { Abunawas can defeat the penghulu }\end{array}$ \\
\hline 1.3 & $\begin{array}{l}\text { Lêmbu nênêm ingkang sagêd wicantênan [Six cows that } \\
\text { can converse] }\end{array}$ & Abunawas has to solve Sultan's challenge \\
\hline 1.4 & $\begin{array}{l}\text { Abunawas anyade Sang Prabu Harun Al Rasid } \\
\text { [Abunawas sells the Sultan Harun Al Rasyid]. }\end{array}$ & Abunawas has a trick to sell the King \\
\hline 1.5 & $\begin{array}{l}\text { Abunawas sakit, badhe gadhah anak [Abunawas was } \\
\text { sick to give birth] }\end{array}$ & Abunawas makes a metaphor to defeat the King \\
\hline 1.6 & $\begin{array}{l}\text { Wurung dipun sapu malah angsal ganjaran arta dinar. } \\
\text { (Not to get punishment; instead, he got dinar) }\end{array}$ & Abunawas meets the King's challenge \\
\hline 1.7 & $\begin{array}{l}\text { Botên ngêmungakên babon, sanajan mantri ugi sok } \\
\text { anigan (Not only the females, but the ministers are also } \\
\text { able to spawn) }\end{array}$ & Abunawas was able to win the competition \\
\hline 1.8 & $\begin{array}{l}\text { Abunawas badhe dipun sêmbêlèh (Abunawas will be } \\
\text { slaughtered) }\end{array}$ & Abunawas's trick to get rid of the Bedouin \\
\hline 1.9 & $\begin{array}{l}\text { Abunawas kalihan lumpang kênthèng (Abunawas and the } \\
\text { mortar) }\end{array}$ & Abunawas mees the King's challenge \\
\hline 1.10 & Kauling sudagar (the Merchant's vow) & $\begin{array}{l}\text { Abunawas helps the merchant to meet his } \\
\text { nadzar/vow. }\end{array}$ \\
\hline
\end{tabular}


Table 2. The List of Stories in Book 2

\begin{tabular}{|c|l|l|}
\hline No & Stories & Theme \\
\hline 2.1 & $\begin{array}{l}\text { Tiyang mlarat kalihan balumbang ingkang asrêp toyanipun. } \\
\text { [Poor man and a cold pool] }\end{array}$ & $\begin{array}{l}\text { Abunawas advocates the poor to enforce } \\
\text { justice }\end{array}$ \\
\hline 2.2 & $\begin{array}{l}\text { Lêmbunipun sang prabu kawulang ngaos Kuran dening } \\
\text { Abunawas. [Abunawas taught the Caliph's Cow Qoran] }\end{array}$ & Abunawas meets the Sultan's challenge \\
\hline 2.3 & Abunawas kalihan tiyang Yahudi [Abunawas and the Jews] & Abunawas can overcome the Jews \\
\hline 2.4 & $\begin{array}{l}\text { Sang Prabu Harun Al Rasid dipun têmpiling dening tiyang } \\
\text { Yahudi [Sultan Harun was slapped by the Jews] }\end{array}$ & $\begin{array}{l}\text { Abunawas made a trick to Sultan Harun Al } \\
\text { Rasyid }\end{array}$ \\
\hline 2.5 & Sima ingkang ajenggot [bearded cow] & Abunawas meets Sultan's challenge \\
\hline 2.6 & $\begin{array}{l}\text { Abunawas kalihan pengulu [Abunawas and the headman] } \\
\text { Abunawas defeats the Sultan and the } \\
\text { headman about the name of the baby. }\end{array}$ \\
\hline 2.7 & Abunawas ngusung masjid [Abunawas moved the mosque] & Abunawas meets the Sultan's challenge \\
\hline
\end{tabular}

In the stories we can find some other changes, like the word "Sultan" in Arabic culture is the title for the king or the highest rank in the society. However, in the Javanese version, instead of using Sultan, it uses "Prabu" (Javanese noun), which means the king. So in the Javanese version, the Harun Al Rasyid is not a Sultan; he is a Prabu, he becomes a Javanese King.

Who are the poor people in Abunawas stories? The main character, Abu Nawas himself, is poor, but as the poet under Sultan patronage, Abu Nawas has got some facilities that make him happy and have no problem with money. The poor people in the stories are not highly varied. We can find out at least four examples of the poor people in the stories. In story 2.1 , the poor person is the one who tried to win the competition to swim in the freezing pool owned by a wealthy merchant. The poor in this story was able to accomplish the mission, to bathe in the freezing pool the whole night. The poor man was making a great effort to do the mission, but the merchant did not give the money as a reward. Instead, he accused the poor of cheating. In this debate and confusion situation, nobody helps the poor man. Abu Nawas then heard about this issue, so that he made a plan to help the poor and enforce social justice, and Abu Nawas is successful in helping the poor get his reward.

The poor in story 1.6 is an old woman, whom Abu Nawas asked her to pretend as his mother, to meet King Harus Al Rasyid. The woman was asked not to tell who she was and obey his order. As a return, the poor woman will get some money. However, the poor old woman could not keep silent in front of the King, and she told the King all the actual situation of herself. The Sultan was made to Abu Nawas accusing him of making a deception. However, in the way to go out from the kingdom, the old woman got punishment from Abu Nawas, and then, they are called back by the
Sultan. As Abu Nawas' smart logic, he got some money from the King.

The other poor people in the stories are the Bedouin communities. The Bedouin usually live in the desert or the village far from the city. They do not have much economic and social access, so that they just live at the primary level. In story 1.8, Abunawas will be slaughtered by the Bedouin people to make the dishes. Bedouin here is represented as the poor and brutal people, who have no understanding of the rules, or civic society. The Bedouin people are stereotyped as the barber people, and with such poverty, this is evidence that the kingdom did not attempt to build welfare for anybody. The king is considered failed because many people under his reign are still in poverty. In this story, Abu Nawas was caught by Bedouin people and their habit to make their capture as their food. Realizing this situation, Abu Nawas got the idea to ask for a substitution. Abu Nawas promised to give another fat guy that is good for food. Abu Nawas asked Sultan Harun to go with him, and the Bedouin captured the King. Abu Nawas's trick has two purposes: to make himself free from the Bedouin and test the Sultan whether or not he could free himself from the Bedouin. The other agenda that Abu Nawas planned was to make the Sultan understand the actual condition of the poor people that he had to take care of under his Kingdom.

As in the stories, Abu Nawas is the main character always represented in each of the titles. Abu Nawas was represented as a poor, common people. It is also under Abu Nuwas' real life in which he came from a poor family. When he was still a boy, her mother sold him to the slave trade. Only because of his prominent poetic talent did he attract the Sultan so that he was under the Sultan's patronage. Abu Nawas, an ordinary 
person, makes the story popular in many different communities and various countries.

Not only represented as common people but Abu Nawas is also represented as the advocate of the poor through his ability in making negotiate. In almost all of the stories, Abu Nawas had to make negotiations with the Sultan, with merchants, with Kadi (Judge), all of them are the high-rank people in the society. In some cases, Abu Nuwas also made negotiated with the same ordinary people, that is, making negotiation with Bedouin people. The Bedouin people are the rural and barbar people, who were accustomed to capturing human beings the same as people hunting animals. This story shows that Bedouin people believed that human beings and animals are just the same degrees. They are all the prey when they can capture them.

The stories of the low-class people above present the social context of the stories of Abu Nawas. Abu Nawas positions himself as the ordinary people who negotiated the high-rank people, like Kadi, Sultan Harun Al Rasyid, and merchants. The social context of the original stories is Baghdad. Historically, the real Sultan Harun Al Rasyid was considered mythically as the King who was wise and popular among the people. The social context of Baghdad was kept original, but the themes and messages of the story may happen to any society at large, including in Javanese society. In the Javanese social-cultural context, the story of Abu Nawas also gets its similar context, in which a lowclass man like Abu Nawas, with his smart and witty attitude, can make negotiations with other higher social rank people, like the king, merchant, and the kingdom officer.

The macro analysis or social context of the study of Abu Nawas can also be seen in the Javanese cultural context. In Javanese myths based on the story presented in traditional puppet or wayang, a group of figures popularly known as the low-class people who made a lot of contribution in society. The group of people is called "punakawan." Punokawan consists of four people; they are Semar as the leader or father of the other three young men, Petruk (like the pseudo name of the translator of this book), Bagong, and Gareng. Petruk is the middle child. The punakawan is portrayed as living together as a harmonious family. They represent the common people and take roles as an entertainer, giving jokes and comics in the puppet show. On many occasions, Dalang (the puppeteer) uses the Punokawan as the channel to criticize, or satire the social issues, in amusing ways. The session of this Punokawan is called "goro-goro," which has become a favorite for the audiences because this session is enjoyable, amusing, and full of laughter.
The issues represented in the stories of Abu Nawas are produced by addressing many problems in society. In the actual context nowadays, many kinds of social issues are often addressed by using the allusion of $\mathrm{Abu}$ Nawas. The story of Abu Nawas is kept reproduced in many contexts. For example, the children's story represented in the story "Kebijaksanaan untuk Dijual" [Wisdom for Sale], which is uploaded in the YouTube channel "Indonesian Fairy Tales," has a similar plot and logic as Abu Nawas story. The children's story tells us how a very young boy named Sheero can sell wisdom, which is commonly considered abstract. Sheero, a typical boy from a low-income family, can survive because of his smart thought. He can sell the wisdom in the market, along with other people, sell and buy basic staples. Through the wisdom he sells, he can save people and the King.

The ideology represented in the stories of $\mathrm{Abu}$ Nawas is that advocating for poor people can be done by the individual or the people of the same class. The success of advocating is determined by the ability to think and use logic and wisdom. These stories did not say that all poor people need to be advocated. Some other poor people need to be given some lessons like the old woman and the Bedouin. They were poor people, but they are negotiated in different ways. Abu Nawas was evidenced to be the example of the people who were survived not because of his blood and heredity but because of his ability to develop himself to obtain the symbolic capital of critical thinking.

\section{CONCLUSION}

It can be concluded that Abu Nawas stories present the ideology that the ordinary people, Abu Nawas, are the hero in social life. His status as common people, with no high social rank did not hinder him from being respected by other people because of his ability to win the negotiation and advocate for other poor people who did not have anybody else to help. Abu Nawas' poetic and logical capability gives him symbolic capital to be confident enough to win the competition or negotiate with anybody in a higher social rank. It is evidenced in the story, the Sultan himself crosses the social border by being so close to Abu Nawas, instead of his position of the King, so that his life was at risk on many occasions.

With such content of values represented in the tales of Abu Nawas, readers get the example of how ordinary people do resistance and negotiate with other people in the same class or different classes. The values of empathy and solidarity to the people in need make tales like Abu Nawas worth being read anytime. 
In Addition, the funny stories also inspired readers to learn the narrative style of the tales.

\section{REFERENCES}

[1] P.K. Hitti, "History of the Arabs". MacMillan. 1970.

[2] P. Kennedy, "The Wine Song in Classical Arabic Poetry: Abu Nuwas and the Literary Tradition”. Oxford: Clarendon Press. 1997

[3] Petruk. "Abu Nawas; Pêthikan saking cariyoscariyos kina." Jilid 1. Wèltêprèdhên: Bale Pustaka. 1930. https://www.sastra.org/kisahcerita-dan-kronikal/cerita/1832-abunawas-jilid1-petruk-1930-1821

[4] R. Allen, "The Wine Song in Classical Arabic Poetry: Abu Nuwas and the Literary Tradition, by Philip F. Kennedy (Book Review)." Middle East Journal, vol. 53, no. 1, pp. 134, 1999.

[5] W. H. Ingrams. "Abu Nuwas in Life and in Legends". Mauritus. 1930

[6] W. H. Ingrams. "Abu Nuwas in life and in Legend”. No. m 4 Al. -, 1933.

[7] L. Y. Fang. “ A History of Classical Malay Literature", Jakarta: Yayasan Pustaka Obor Indonesia. 2013.
[8] Republika.co.id. "Mengenal Abu Nuwas". [Get to know Abu Nawas]. 18 Aug 2020.

[9] Republika.co.id. "Abu Nawas, Penyair atau Pelawak?" [Abu Nawas is a Clown or a Poet?]. 14 March 2015.

[10] Indonesian Fairy Tales. "Kebijaksanaan untuk Dijual” [Wisdom for Sale]. YouTube. 2020

[11] Petruk. "Abu Nawas; Pêthikan saking cariyoscariyos kina.” Jilid 2. Wèltêprèdhên: Bale Pustaka. 1930.

https://www.sastra.org/kisah-cerita-dankronikal/cerita/1832-abunawas-jilid-2-petruk$\underline{1930-1821}$

[12] A. Kresna, "Punakawan: Simbol Kerendahan Hati Orang Jawa" [The Punakawan: Symbol of the Humility of Javanese People]. Yogyakarta: Narasi. 2012.

[13] N. Fairclough, "Critical Discourse Analysis: The Critical Study of Language". London \& New York: Longman. 1997

[14] Abu Nuwas. Encyclopedia.com https://www.encyclopedia.com/people/literatureand-arts/asian-literature-biographies/abu-nuwas 